References

1. Lavretsky H. The Russian concept of schizophrenia: a review of the literature. Schizophr Bull. 1998;24(4):537-57.

2. Jenkins R, Klein J, Parker C. Mental health in post-communist countries. BMJ. 2005;331(7510):173-4.

3. Jargin SV. Overdiagnosis of schizophrenia: A view from Russia. Asian J Psychiatr. 2009;2(3):119.
4. Jenkins R, McDaid D, Nikiforov A, Potasheva A, Watkins J, Lancashire S, Samyshkin Y, Huxley P, Atun R. Mental health care reforms in Europe: Rehabilitation and social inclusion of people with mental illness in Russia. Psychiatr Serv. 2010;61(3):222-4.

5. Fulford KW, Smirnov AY, Snow E. Concepts of disease and the abuse of psychiatry in the USSR. BrJ Psychiatry. 1993;162:801-10.

\section{Evidence of persistent executive function deficits in cannabis dependence after one month of abstinence}

\section{Evidências de déficits executivos persistentes após um mês de abstinência na dependência de maconha}

FAB SCORE

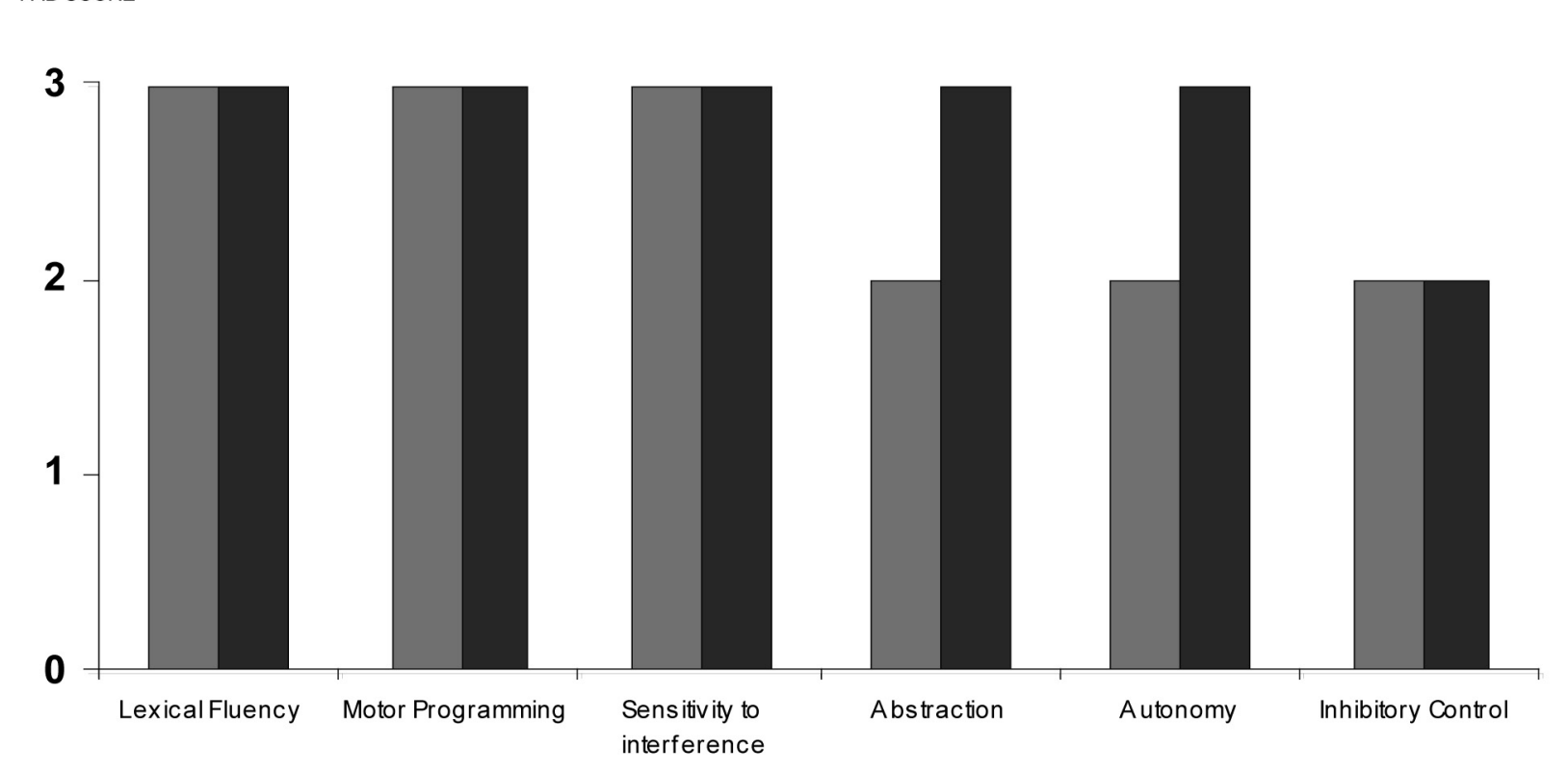

¿ 1st Neuropsychological Assessment (NA)

a 2nd Neuropsychological Assessment (NA)
Dear Editor,

Marijuana is the most commonly used illicit drug around the world. Information about risks is important for prevention and treatment strategies. In this regard, a relevant and well conducted review article was published in the Revista Brasileira de Psiquiatria by Almeida et al., which has concluded that chronic cannabis users (CCU) present executive cognitive functions (ECF) deficits. The authors reviewed nine studies of CCU that showed impaired abstract reasoning, concept formation, and mental flexibility. ${ }^{1}$ ECF may represent a very relevant target for rehabilitation strategies, since ECF deficits are associated with poorer outcomes in treatment. ${ }^{2}$ In addition, the literature discussing whether ECFrelated deficits persist after a period of abstinence is contradictory. ${ }^{3}$ Pope et al. did not find evidences to support that CCU who were 28-day abstinent have persistent ECF-related deficits. ${ }^{4}$

Figure 1 - Executive cognitive functioning in the six domains of the Frontal Assessment Battery (FAB). 
Table 1- Neuropsychological follow-up study of a cannabis-dependent patient during the first month of abstinence

\begin{tabular}{|c|c|c|c|}
\hline Neuropsychological tests & $\begin{array}{c}1^{\text {st }} \mathrm{NA} \\
\text { (During the } 1^{\text {st }} \text { week of } \\
\text { abstinence) }\end{array}$ & $\begin{array}{c}2^{\text {nd }} N A \\
\text { (After one month of } \\
\text { abstinence) }\end{array}$ & Evolution \\
\hline \multicolumn{4}{|l|}{ Trail Making Test (TMT) } \\
\hline Part A & Low average & Average & + \\
\hline Part B & Borderline & Low average & + \\
\hline \multicolumn{4}{|l|}{ Stroop Color Word Test (SCWT) } \\
\hline Part I & Very poor & Very poor & $=$ \\
\hline Part II & Very poor & Average & + \\
\hline Part III & Average & Average & $=$ \\
\hline Controlled Oral Word Association Test (COWAT) & Average & High average & + \\
\hline The Rey-Osterrieth Complex Figure Test (ROCFT) & Low average & Superior & + \\
\hline Forward Digits (FD), WMS-III & Average & Low average & - \\
\hline Backward (BD), WMS-III & Borderline & Low average & + \\
\hline Spatial Span (WMS-III) & Average & Average & $=$ \\
\hline \multicolumn{4}{|l|}{ Wisconsin Card Sorting Test (WCST) } \\
\hline Categories Completed & High average & High average & $=$ \\
\hline Perseverative Errors & Low average & High average & + \\
\hline Failure to maintain set & Average & Low average & - \\
\hline \multicolumn{4}{|l|}{ lowa Gambling Test (IGT) } \\
\hline Netscore & -10 & 14 & + \\
\hline \multicolumn{4}{|l|}{ Frontal Assessment Battery (FAB) } \\
\hline Total score & 15 & 17 & + \\
\hline Vocabulary (WAIS-III) & High average & $\mathrm{NE}$ & \\
\hline Block Design (WAIS-III) & Average & NE & \\
\hline \multicolumn{4}{|c|}{$\begin{array}{l}\text { NA: neuropsychological assessment; WMS-III: Wechsler Memory Scale - Third Edition; WAIS-III: Wechsler Adult Intelligence Scale - Third } \\
\text { Edition; results are shown according to the normative data (from the worst to the best cognitive functioning): Very Poor, Borderline, Low } \\
\text { Average, Average, High Average, Superior, and Very Superior; IGT and FAB results' are shown in raw scores; evolution: differences between } \\
\text { the first and the second NA, [ + ] regarding improvement, [ =] no differences; [-] worsening; NE: these tests were not used in the } 2^{\text {nd }} \text { NA, due to } \\
\text { the irrelevance of measuring intellectual efficiency again. }\end{array}$} \\
\hline
\end{tabular}

However, Bolla et al. suggested that heavy CCU had persistent dose-related cognitive and ECF-related deficits on a range of neuropsychological tests, even after 28 days of abstinence. ${ }^{5}$ The aim of this letter is to report a case study that met the diagnostic criteria for cannabis dependence and was followed for a period of 30 days in an inpatient unit. After signing the informed consent, the patient was submitted to a very careful neuropsychological assessment (NA) focused on ECF, at the treatment entry ( $\left.1^{\text {st }} \mathrm{NA}\right)$ and after 30 days $\left(2^{\text {nd }} \mathrm{NA}\right)$.

Case report: A 36 year-old man was admitted to the impulsive behavior ward of the Institute of Psychiatry (IPq), Clinicas Hospital, Medical School, Universidade de São Paulo (FMUSP). He was 13 years old when he began to smoke cannabis and he was 16 when he started to use it almost weekly (every weekend). His cannabis use increased progressively and at 20 years old he started to smoke daily (one week was the maximum withdrawal period) until he was admitted to the ward unit. He has been using three joints a day during the last eight months. The NA was based mainly on ECF-related tests. The results in the $1^{\text {st }} \mathrm{NA}$ showed good estimated intellectual efficiency (Intellectual Quotient, IQ: 105, average), semantic knowledge (vocabulary, from the Wechsler
Adult Intelligence Scale, Third Edition, WAIS-III) and verbal fluency (Controlled Oral Word Association Test, COWAT - see Table 1), although the tests demonstrated neuropsychological impairments in processing speed/basic attentional processes (Trail Making Test, TMT - part A, Stroop Color Word Test, SCWT - parts I and II), working memory (Backward Digits, BD), planning (The Rey-Osterrieth Complex Figure Test, ROCFT), decision making (Iowa Gambling Test, IGT), abstraction (Frontal Assessment Battery, FAB, subtest), ${ }^{6}$ autonomy (FAB subtest) and inhibitory control (FAB subtest) corresponding to deficits associated with CCU in the literature. ${ }^{4,5}$ After one month of abstinence ( $2^{\text {nd }} \mathrm{NA}$ ), which was verified by self-report and supervised by the clinical staff, there was an improvement in decision-making, planning, verbal fluency, abstraction and autonomy, as well as a slight improvement in working memory and mental flexibility (perseverative errors - Wisconsin Card Sorting Test, WCST). In spite of this, his performance on ECF tasks such as TMT - Part B and BD remained somewhat below the normal range (Low Average). Additionally, the patient remained with an important deficit in the FAB's inhibitory control subtest (Figure 1) and he had a poorer performance in attention span 
(Forward Digits, FD) and failures to maintain set in WCST. In his daily life he had problems associated with finances, job, and family (the patient was unable to financially support himself and to have a satisfactory relationship with his parents, especially with his mother).

It is relevant to highlight that in the $1^{\text {st }}$ and $2^{\text {nd }} \mathrm{NA}$, the patient has showed apparently unexpected superior results in WCST (especially in completed categories). Yet, WCST impairment findings in CCU are rather inconsistent. ${ }^{4,5}$ Also, his abstraction performance in WCST corresponds to his good estimated premorbid intellectual efficiency (showed by Vocabulary - WAISIII). On the other side, his poor performance on the TMT and on the SCWT (part I and II) could have occurred due to processing speed deficits. It is possible that the patient revealed different performances on diverse tests (WCST, TMT and SCWT), because they measure distinct functions.

Despite some improvement in ECF, the patient did not reach a normal functioning in the $2^{\text {nd }} \mathrm{NA}$. Also, the FAB detected inhibitory control impairments that persisted throughout the period of one month of abstinence. Considering that there were no differences regarding the severity of depressive and anxious symptoms between the $1^{\text {st }}$ and $2^{\text {nd }} \mathrm{NA}$, the persistent ECF-related deficits were unlikely to be associated with withdrawal effects.

In conclusion, even after 30 days of withdrawal, ECFrelated deficits were observed in cannabis dependence that may be associated with problems in the patient's daily life. The improvement seen in certain cognitive functions should be carefully interpreted. First, where there were indeed improvements, they were modest, and impaired performance appeared to persist across many measures. Second, certain neuropsychological tasks such as ROCFT are subject to practice effects due to repetitive testing. Longitudinal studies are needed for further investigation on the persistence of ECF changes and the impact on the daily activities of cannabis users.

Priscila Dib Gonçalves, André Malbergier, Arthur Guerra de Andrade

Interdisciplinary Group of Studies on Alcohol and Drugs (GREA), Department of Psychiatry (IPq), Medical School, Universidade de São Paulo (USP), São Paulo SP, Brazil

Maria Alice Fontes

Interdisciplinary Laboratory of Clinical Neurosciences (LiNC), Department of Psychiatry, Universidade Federal de São Paulo (UNIFESP), São Paulo, SP, Brazil

Paulo Jannuzzi Cunha Interdisciplinary Group of Studies on Alcohol and Drugs (GREA), Department of Psychiatry (IPq), Medical School,

Universidade de São Paulo (USP), São Paulo SP, Brazil

Equilibrium Program, Institute of Psychiatry (IPq), Universidade de São Paulo (USP), São Paulo SP, Brazil

Disclosures

\begin{tabular}{|c|c|c|c|c|c|c|c|}
\hline $\begin{array}{l}\text { Writing group } \\
\text { member }\end{array}$ & Employment & $\begin{array}{c}\text { Research } \\
\text { grant }^{1}\end{array}$ & $\begin{array}{c}\text { Other research grant } \\
\text { or medical continuous } \\
\text { education }\end{array}$ & $\begin{array}{l}\text { Speaker's } \\
\text { honoraria }\end{array}$ & $\begin{array}{l}\text { Ownership } \\
\text { interest }\end{array}$ & $\begin{array}{l}\text { Consultant/ } \\
\text { Advisory } \\
\text { board }\end{array}$ & Other $^{3}$ \\
\hline $\begin{array}{l}\text { Priscila Dib } \\
\text { Gonçalves }\end{array}$ & $\begin{array}{c}\text { Departamento } \\
\text { de } \\
\text { Psiquiatria } \\
\text { da FMUSP }\end{array}$ & - & - & - & - & - & - \\
\hline André Malbergier & IPq-FMUSP & $\begin{array}{l}\text { FAPESP } \\
\text { SENAD } \\
\text { Pfizer }\end{array}$ & - & - & - & - & - \\
\hline $\begin{array}{l}\text { Arthur Guerra de } \\
\text { Andrade }\end{array}$ & IPq-FMUSP & $\begin{array}{l}\text { FAPESP } \\
\text { SENAD }\end{array}$ & - & - & - & CISA & - \\
\hline Maria Alice Fontes & $\begin{array}{l}\text { LInC- } \\
\text { UNIFESP }\end{array}$ & CAPES & - & - & - & - & - \\
\hline $\begin{array}{l}\text { Paulo Jannuzzi } \\
\text { Cunha }\end{array}$ & IPq-FMUSP & $\begin{array}{r}\text { FFM } \\
\text { NIDA }\end{array}$ & - & - & - & - & - \\
\hline \multicolumn{8}{|c|}{$\begin{array}{l}\text { *Modest } \\
\text { ** Significant } \\
\text { *** Significant. Amounts given to the author's institution or to a colleague for research in which the author has participation, not directly to the } \\
\text { author. } \\
\text { Note: FMUSP = Faculdade de Medicina da Universidade de São Paulo; IPq-FMUSP = Instituto de Psiquiatria da Faculdade de Medicina } \\
\text { da Universidade de São Paulo; FAPESP = Fundação a Amparo à Pesquisa do Estado de São Paulo; SENAD = Secretaria Nacional de } \\
\text { Políticas sobre Drogas; CAPES = Coordenação de Aperfeiçoamento de Pessoal Nivel Superior; FFM = Fundação Faculdade de Medicina; } \\
\text { NIDA = National Institute on Drug Abuse; CISA = Centro de Informaç̃es sobre Saúde e Álcool. }\end{array}$} \\
\hline
\end{tabular}


References

1. Almeida PP, Novaes MA, Bressan RA, Lacerda AL. Review: executive functioning and cannabis use. Rev Bras Psiquiatr. 2008;30(1):69-76.

2. Aharonovich E, Brooks AC, Nunes EV, Hasin DS. Cognitive deficits in marijuana users: effects on motivational enhancement therapy plus cognitive behavioral therapy treatment outcome. Drug Alcohol Depend. 2008;95(3):279-83.

3. Solowij N, Pesa N. Cognitive abnormalities and cannabis use. Rev Bras Psiquiatr. 2010;32(Suppl 1):S31-40.

\section{Depressão durante a gravidez no sistema público de saúde brasileiro}

\section{Depression during pregnancy in the Brazilian public health care system}

Caros Editores,

Gostaríamos de parabenizar os autores Silva et al. pelo trabalho recém-publicado na Revista Brasileira de Psiquiatria ${ }^{1}$. O artigo avalia a prevalência e fatores associados à depressão em gestantes atendidas por meio do sistema público de saúde da cidade de Pelotas. Trata-se de pesquisa de enorme relevância para a saúde pública que aborda tema frequentemente relegado a plano secundário na assistência às gestantes. O estudo mostra que $21 \%$ das participantes apresentam episódio depressivo na gravidez, ressaltando a importância do papel do profissional de saúde no diagnóstico precoce e adoção de medidas terapêuticas. No entanto, gostaríamos de fazer um reparo ao trabalho e comentar seus resultados.

$\mathrm{Na}$ introdução, os autores afirmam que este é primeiro estudo nacional em amostra representativa da população. Nosso artigo "Common mental disorders during pregnancy: prevalence and associated factors among low-income women in São Paulo, Brazil”, publicado no periódico Archives of Womens' Mental Health, em
4. Pope HG, Gruber AJ, Hudson JI, Huestis MA, Yurgelun-Todd D. Neuropsychological performance in long-term cannabis users. Arch Gen Psychiatry. 2001;58(10):909-15.

5. Bolla KI, Brown K, Eldreth D, Tate K, Cadet JL. Dose-related neurocognitive effects of marijuana use. Neurology. 2002;59(9):1337-43.

6. Cunha PJ, Nicastri S, Andrade AG, Bolla KI. The Frontal Assessment Battery (FAB) reveals neurocognitive dysfunction in substancedependent individuals in distinct executive domains: abstract reasoning, motor programming, and cognitive flexibility. Addict Behav. 2010;35(10):875-81.

$2009^{2}$, avaliou um grupo de 831 gestantes com características sociodemográficas muito semelhantes atendidas em pré-natal nas unidades de atenção primária do sistema público de saúde da região Oeste da cidade de São Paulo. Gostaríamos de destacar que a prevalência de depressão/ansiedade avaliada por meio da Clinical Interview Schedule-Revised (CIS-R) foi igualmente de 20\%. Quanto aos fatores associados à depressão, também observamos que história de tratamento psiquiátrico prévio, uso de álcool e tabagismo mostraram-se fortemente associados com prevalência de depressão. Também do mesmo modo que o observado por Silva et al. ${ }^{1}$, não ter parceiro $(\mathrm{p}=0,09)$ e baixa escolaridade $(0,02)$ se associaram com depressão apenas na análise univariada. Por outro lado, diferentemente dos resultados do estudo de Pelotas, não encontramos associação entre depressão na gestação e número de gestações anteriores, gravidez planejada ou ter mais idade. Pelo contrário, em nossa amostra, a idade mais jovem na gestação atual é que apresentou associação estatisticamente significante com o desfecho em questão, sugerindo que talvez fatores contextuais possam modificar a associação entre idade e depressão na gravidez.

Por se tratar de problema tão prevalente e com potenciais consequências para a mulher e para o bebê, a exemplo de nossos colegas de Pelotas, acreditamos que novas pesquisas nacionais sobre depressão no ciclo gravídico-puerperal são necessárias para auxiliar no desenvolvimento de programas e políticas públicas que permitam melhorar efetivamente a assistência às gestantes oferecida pelo Sistema Único de Saúde do país.

Alexandre Faisal-Cury, Paulo Menezes Departamento de Medicina Preventiva, Faculdade de Medicina, Universidade de São Paulo (USP), São Paulo, SP, Brasil

\section{Disclosures}

\begin{tabular}{|c|c|c|c|c|c|c|c|}
\hline $\begin{array}{l}\text { Writing group } \\
\text { member }\end{array}$ & Employment & $\begin{array}{l}\text { Research } \\
\text { grant }^{1}\end{array}$ & $\begin{array}{c}\text { Other research grant } \\
\text { or medical continuous } \\
\text { education }^{2}\end{array}$ & $\begin{array}{l}\text { Speaker's } \\
\text { honoraria }\end{array}$ & $\begin{array}{c}\text { Ownership } \\
\text { interest }\end{array}$ & $\begin{array}{l}\text { Consultant/ } \\
\text { Advisory } \\
\text { board }\end{array}$ & Other ${ }^{3}$ \\
\hline Alexandre Faisal-Cury & USP & - & - & - & - & - & - \\
\hline Paulo Menezes & USP & - & - & - & - & - & - \\
\hline
\end{tabular}

